\title{
Reading in the era of globalization and information technologies in contemporary society
}

\section{La lectura en la era de la globalización y las tecnologías de la información en la sociedad contemporánea}

\author{
CRUZ-CRUZ, Irasema† \& GÓMEZ-SÁNTIZ, María Magdalena \\ Universidad Autónoma de Chiapas, Faculty of Humanities Campus VI \\ $1^{\text {st }}$ Author: Irasema, Cruz-Cruz, ORC ID: 0000-0002-0407-351X, CVU CONACYT ID: 432517 \\ $1^{\text {st }}$ Coauthor: María Magdalena, Gómez-Sántiz / ORC ID: 0000-0002-4441-0322, CVU CONACYT ID: 103981
}

DOI: $10.35429 /$ EJS.2019.11.6.10.15

Received September 10, 2019; Accepted December 15, 2019

\begin{abstract}
We must analyze literacy in general and in particular the so-called digital literacy as a sociocultural problem linked to the formation of individuals. Every social or technological change has always demanded a profound transformation from humanity, due to the vertiginous advances that have occurred; Throughout history, man has seen the need to transform some practices. Reading has been one of the fundamental axes because the human being has required addressing and being able to face the challenges facing globalization and information technologies. The deep and rapid transformations in all fields of modern life are something that characterizes the world in which we live. The new forms of communication have accelerated, a revolution of wide scope that revolves around the transformation of the mechanisms of production, diffusion and access to information, as well as in the expressive and representative languages of culture and knowledge. In universities, they must identify the areas that need to be strengthened to support students in carrying out the readings responsibly.
\end{abstract}

Reading, globalization, information technocologies

\begin{abstract}
Resumen
La alfabetización en general y de modo particular la denominada alfabetización digital, tenemos que analizarla como un problema sociocultural vinculado con la formación de los individuos. Desde siempre todo cambio social o tecnológico exige de la humanidad una transformación profunda, por los avances vertiginosos que han ocurrido; a lo largo de la historia el hombre se ha visto en la necesidad de transformar algunas prácticas. La lectura ha sido uno de los ejes fundamentales pues el ser humano se ha visto en la necesidad de atender y poder enfrentar los retos ante la globalización y las tecnologías de la información. Las profundas y rápidas transformaciones en todos los campos de la vida moderna es algo que caracteriza al mundo en que vivimos. Las nuevas formas de comunicación han acelerado, una revolución de amplio alcance que gira en torno a la transformación de los mecanismos de producción, difusión y acceso a la información; así como en los lenguajes expresivos y de representación de la cultura y el conocimiento. En las universidades deben identificar las áreas que requiere fortalecerse para apoyar a los estudiantes en realizar las lecturas de forma responsable.
\end{abstract}

Lectura, globalización, tecnologías de la información

Citation: CRUZ-CRUZ, Irasema \& GÓMEZ-SÁNTIZ, María Magdalena. Reading in the era of globalization and information technologies in contemporary society. Journal-Spain. 2019. 6-11: 10-15

$\dagger$ Researcher contributing as first author. 


\section{Introduction}

Nowadays, many people have considered that reading is an unpleasant and sometimes dull activity; however, this should not be conceptualized as such because when encountering the printed and the unprinted, the reading subject acquires a lot of experience and knowledge. So reading is for: cultivating oneself, informing oneself of events that society is experiencing; furthermore, it allows for more significant enrichment in verbal expression, for which reason we could understand reading as an action to strengthen cultural and academic practice and social activity.

Reading and writing are not that personal, non-transferable act, or the opposite as an instrumental means, but rather it is the critical component of social communication. The supports have very much conditioned reading; the materiality, the way one writes and how one publishes, since what is written marks completely different forms of reading Barbero (2005) that is, they are socially and culturally diverse forms, with different political and economic conditions of reading; therefore, one cannot teach reading only so that people read alone in their room, at home, or in their bus seat etc; reading is much more than that.

In that sense, we could recover the historical practices that have not disappeared and that are superimposed to the more modern ones since previously reading was linked to reaching a certain age; even in the families in which books, letters, telegrams used to be read aloud, an activity that was done by grandparents or parents. However, today reading as a social activity and practice has had its variations. Viñao (2007), points out that, reading as an activity has a non-universal character that is changeable and unrepeatable and that currently offers a wide diversity of practices; such practices can refer, among other aspects, to the physiological implications of the body in reading, the environment or context in which is read, the character or status of what is read, the types of writing, the uses (contexts of use and purposes) and the position of the subject that reads in relation to the text. All of these, by themselves, or combined, determine and imply different practices for appropriating the reading.
The different ways of looking at research that made up the methods of qualitative research, among them life stories, based on giving people a voice as they construct reality, without the nuances of the researcher as regularly occurs from the positivist perspective. The life story is complemented with other testimonies and techniques where the participation of the researcher becomes more present in the interpretations that he makes when he joins the data from different sources.

Through dialogic exercise, two university students of 2nd and 8th semesters of the Pedagogy Degree in the Pijijiapan Extension of the Autonomous University of Chiapas are given a voice. Through the biographic technique, it was useful to know the reconstruction that the students do of their life trajectory giving special attention to the processes that they have lived in their reading formation.

\section{Reading in the age of globalization and information technologies in contemporary society}

Today it is possible to understand globalization as a series of multidirectional processes and not merely as the internalization of cultures and messages that used to be separated from one another. "Globalization presses not only upwards, but also downwards creating new pressures for local autonomy" (Giddens, 2009: 1082); these pressures have generated that globalization, among them the use of the internet, other forms of exchange maintain new modes of solidarity between subjects, from the chains of messages to the forms of isolation by the lack of face to face communication, but at the same time, approach by interactions through any technological device.

Reading is a human activity, where the reader comes into contact and communication with great thinkers; that is, it is an interactive process between the reader and the text. According to Oseguera and Chávez (1991), the term reading comes from the verb lectum, which is a nominal form of the Latin verb legere, the primary meaning of which is "to choose," "to select." Consequently, reading means the action of selecting, and the selection itself. Returning to the etymological origin of the term, we could say that reading is the interpretation and selection of a message that is received in writing. 
The new information and communication technologies have provoked, or at least accelerated, a far-reaching revolution in our civilization that revolves around the transformation of the mechanisms of production, storage, dissemination and access to information; in the forms and flows of communication between people; as well as in the expressive and representative languages of culture and knowledge. The new times have generated new forms: internet, mobile telephony, video games and other digital items that are changing multiple aspects such as: in leisure, in personal communications, in learning, in work, etc.

The term new technologies refers to "all those technical equipment or systems, the set of tools, supports and channels for access to information" (Monereo, 2005: 17). It is for this reason that new technologies are used for pedagogical purposes, extending their possibilities of use in the processes of teaching and learning, allowing the elaboration of didactic materials, oriented to multiply the effects of training activities on the individual, they can motivate the eagerness to know, the desire to learn, create in the student skills for his self-preparation, through which the desire to learn is awakened, one learns to study, to use knowledge and to develop thought.

We must analyze literacy in general and, in particular the so-called digital literacy, as a socio-cultural problem linked to the formation of citizenship and as one of the most important challenges for the policies of educational institutions aimed at equal opportunities in access to culture. From this perspective, it should represent a process of developing an identity as a subject in the digital territory, characterized by the significant appropriation of the intellectual, social and ethical skills needed to interact with information. The possible goal of digital literacy is to develop in each subject the capacity to act autonomously, a right to a need of every citizen in the information society.

Every social or technological change demands from humanity a profound, transcendental transformation, that is to say, that for each one of the advances that have been presented throughout history man is changed according to his needs, which can be intellectual and psychological changes, leading him to be different perhaps from any previous model.
Likewise, it is important to establish that in every process of transformation that the human being has had, reading has been one of the fundamental axes because humans have seen the need to attend and be able to face the challenges before globalization and the information technologies.

The deep and rapid transformations in all fields of modern life is something that characterizes the world in which we live. Computing, informatics, telematics, fax, e-mail, multimedia, electronic networks; in short, what is known today as the New Information and Communication Technologies (ICTs) are fundamental acts of socio-economic progress and its dizzying development that are influencing economic, political and social relations of humanity.

Gutiérrez (2003) has shown that the acquisition of skills in the intelligent use of new technologies requires, at least, instrumental mastery together with the acquisition of skills related to the search, analysis, selection and communication of data and information so that students can transform information into knowledge and develop skills of communicative interaction in digital environments. Appropriation of the meaning and multimodal expression would be the new terms of the old concepts of reading and writing that have been traditional in all literacy processes.

\section{Reading in the Mexican education system}

The Sectorial Program for Education 2007-2012, proposed by the Ministry of Education (SEP) (2007) establishes that "the Mexico of the new millennium demands that the National Education System trains its future citizens as persons, as conscious human beings, with identity, rights and duties, creators of values and ideals" (p.5).

In this sense, we may consider that schools as educational institutions are places where students should find adequate conditions for the full development of their abilities and potential with reading as an instrument of use at all levels of education. Although promoting reading through literacy has indeed been a priority, it is essential to point out that the concept of education in our country proposes it as the basis for the progress of nations and the well-being of peoples. 
The Education Sector Programme considers education to be a fundamental element for development and a route par excellence for social mobility. It also establishes that the State and society must promote quality education that is part of the exercise of freedom with the development of skills, abilities and attitudes. It is necessary to specify from the sociological analysis that what is related to social mobility would be subjected to the status quo of each individual to access other work opportunities. This reflection can lead to a rethinking of the problem of education in order to identify the areas that should be strengthened in public schools with the most significant responsibilities of the State and of municipalities in educational action without losing sight of the work of teachers as the principal agents of student training.

Concerning the role of reading in the education system, we identify sector objective, which establishes that "The quality of education must be raised so that students improve their level of educational achievement, have the means to access greater well-being and contribute to national development" (SEP, 2007: 11). Among the complementary actions to promote reading, proposed by the programme, we identify the following:

- $\quad$ To encourage the habit of reading in the population as a fundamental tool for learning and a way to access knowledge. To promote the improvement of educational material distribution services.

To train readers and writers, from school, is a task that must have teachers who have incorporated the written culture into their lives and, besides, have substantial training in teaching processes and communication skills" (SEP, 2007:29).

The complementary actions are tasks that we have to carry out from the classroom, taking into account various factors such as family context, the culture of each student, as well as the characteristics that they possess in order to understand and address a major problem with the poor reading comprehension identified in higher-level education. The concern for raising the level of educational achievement, based on reading, has led to the establishment of agreements that must be carried out as obligatory strategies that teachers must know and apply in the classroom.
In this context, full access to written culture at the different educational levels has been considered of great relevance as established in Agreement 429, which issues the operating rules of the National Reading Programme (NLP), supported by article 3 of the Constitution, the National Development Plan 2007-2012. On the other hand, the importance of the analysis of the plans and programs of primary education should not be ignored because it specifies the actions to be developed in the promotion of reading as a fundamental tool for learning:

The Plan and Programs of Studies for Primary Education, contained in Agreement Number 181, published on August 27, 1993, assigns priority to the mastery of reading, writing and oral expression. Similarly, Agreement 384, which establishes the Plan of Studies for Secondary Education, published on May 26, 2006, states that language is acquired and adapted in social interaction through participation in acts of reading, writing and oral exchanges that are varied and full of meaning for individuals. (SEP, 2007: 5).

In order to achieve an adequate balance between the federal and state spheres, particularly about promoting reading as a daily practice, emphasis is placed on the acquisition of knowledge to develop the capacity for reflection and analysis as part of the integral development of students. Learning to read is an evolutionary process in which several stages must be distinguished. Thus, for human beings, learning to read should be a sequential process, that is, that they learn according to the chronological and psychological age; the acquisition and comprehension of reading are far from the ages of the subjects. Therefore, a five-year-old child cannot be required to do a reading as a young adult or adolescent could since we would be putting pressure on him or perhaps causing other problems at the same time.

On the other hand, we could understand that the subject's disposition also has to do with reading practices "it is not the same to read a text voluntarily or freely than to read it obligatorily, or in a more or less imposed way" (Viñao, 2007: 54). In this sense, the school environment can be considered as a space in which the student reads because the teacher indicates so. 
Two different purposes and uses of reading collide: one of a restrictive, compulsory nature and to pass an exam or test. Another aimed at awakening a taste for voluntary reading and open to a multiplicity of texts.

The social influence linked to the very notion of practice is reinforced by the fact that reading belongs to the genre of so-called "cultural" practices. In this sense, we could say that reading obeys the same laws as other cultural practices, with the difference that it is taught directly in the school system, the level of instruction will be more influential in the system of explanatory factors, the secondary factor being one of social origin.

To say that reading is a cultural practice is to understand that it forms, that leads to the information of a personal and social identity, which constitutes a manifestation, a privileged expression of identity. Now, because it is not the identification of oneself or with members of the same group, of the same category of belonging without differentiation with the others, "the cultural practices of some and others are not only socially differentiated, but also socially hierarchical" (Barbero, 2005: 2-3).

In this sense, it is understood that culture constitutes the field par excellence of the game of social domination, where the position occupied in relation to domination is objectified precisely within a "dominant" culture for some and "dominated" for others. In such a way, that the social coercion that weighs on any practice, takes within the field of the cultural practices, and singularly in the reading practices, the characteristic form of the cultural imposition and the effect of legitimacy.

Reading as a social activity and practice is to learn to listen, to learn to have a word of one's own amid a whole society that is to intermingle with several words that say the same thing. In this sense, it is clear to recognize that reading promotes knowledge and opens horizons of new meanings. It allows human beings to integrate, which is why it is essential to promote reading practices at very early ages in different contexts: family, school, and community.
Thus, it will depend on the initiative of each individual with respect to the interest of what he or she wishes to read, independently of whether the student has to read what corresponds to his or her academic formation, and that, of course, this is part of his or her interest in reading, and that also allows him or her to construct autonomy as a reader. All educational processes have as their ultimate goal to provide individuals with the necessary tools to achieve their autonomy, that is to say, the free, tolerant and responsible exercise of the capacity of choice that in real conditions subjects must have in any area of their lives. It is, therefore, a matter of generating the objective conditions to form empowered autonomous subjects. Among these situations, access to reading should be a priority.

\section{In Mexico, Canton points out that:}

All educational action must focus on the specific characteristics, needs, interests, aptitudes and skills of the learner, for the wellbeing of educational activity is a social and collective task par excellence and must be at the service of the particularity of the subjects and be oriented towards their well-being (2009: 98).

For this reason, it is worth reflecting that early reading stimulation should be generated in family environments, strengthening it in primary education so that students can reach higher-level education with all the reading skills that will consolidate their formation. In Mexico, as in other Latin American countries, numerous efforts have been made, not always successfully, to increase reading practice in daily life.

These efforts have not had the expected results, since they are imposed on the educational reality as a circumstantial policy, without taking into consideration the fundamental task of analyzing the history of the formation of readers in our country, and if this formation had the intention that we recognize today as legitimate to form, through reading, autonomous subjects; that is, subjects capable of reading freely and reflectively. The importance of its realization is recognized since, in higherlevel education, we continue to find severe problems concerning reading in which students have pointed out their difficulties in understanding academic texts. 


\section{Conclusions}

Finally, we could consider that reading as a social practice cannot be limited to see it as a simple activity; because "practice" is a concept which means that the activity in question is socially regulated. Like any practice, reading is something placed under the influence of social coercion, as something determined in its different modalities, this means that the different dimensions of reading practice vary according to social factors, that these variations and their regularity are not reflected because social regularity is only reflected in a statistical plan, to the free play of their preferences, of their tastes; on the contrary, they are springs of subjectivity itself, preferences, tastes, those that carry the trace of social coercion, so that the subjects are not the true actors of their practices, but the supports of a social logic that surpasses them, that overflows them and is manifested in the orderly distribution of their practices.

It is important to mention that since reading is a competence taught and learned, and that constitutes one of the minimum indispensable skills for learning, its inclusion in the field of education is natural. In this sense, we could say that since education is the vehicle for the incorporation of subjects into the social pact, it also constitutes the privileged means for citizenship as the result of a training process aimed at the incorporation into social life with rights and duties, following the realization of responsibilities that guide social life.

\section{References}

Barbero, Jesús, M. (2005). Desentrañamiento del libro y estallido de la lectura. Ponencia presentada en el III Congreso Nacional de Lera. Bogota, Colombia.

Cantón, Valentina. (2009). Historia de la lectura en México, hacia la formación de lectores autónomos primera parte.

Guiddens, Anthony. (2009). La Globalización y el mundo en procesos de cambio. En Sociología. Madrid, Spain: Alianza Editorial.

Gutiérrez, A. (2010). "Creación multimedia y alfabetización en la era digital”. In aparici. R. (coordi.). Educomunicación Barcelona: Gedisa.

Oseguera, E. y Chávez, P. (1991). Taller de Lectura y Redacción 2. Mexico: Cultural.
SEP (2007- 2012) Programa sectorial de educación. Mexico

Viñao, A. (2007). "Modos de leer, maneras de pensar". Lecturas intensivas y extensivas. Ethos Educativo. 40, september/december, 42-7 